\title{
MATRIX-VBS (v1.0): implementing an evolving organic aerosol volatility in an aerosol microphysics model
}

\author{
Chloe Y. Gao ${ }^{1,2}$, Kostas Tsigaridis ${ }^{3,2}$, and Susanne E. Bauer ${ }^{3,2}$ \\ ${ }^{1}$ Department of Earth and Environmental Sciences, Columbia University, New York, NY, 10027, USA \\ ${ }^{2}$ NASA Goddard Institute for Space Studies, New York, NY, 10025, USA \\ ${ }^{3}$ Center for Climate System Research, Columbia University, New York, NY, 10025, USA \\ Correspondence to: Kostas Tsigaridis (kostas.tsigaridis@columbia.edu)
}

Received: 2 July 2016 - Discussion started: 14 September 2016

Revised: 29 December 2016 - Accepted: 19 January 2017 - Published: 16 February 2017

\begin{abstract}
The gas-particle partitioning and chemical aging of semi-volatile organic aerosol are presented in a newly developed box model scheme, where its effect on the growth, composition, and mixing state of particles is examined. The volatility-basis set (VBS) framework is implemented into the aerosol microphysical scheme MATRIX (Multiconfiguration Aerosol TRacker of mIXing state), which resolves mass and number aerosol concentrations and in multiple mixing-state classes. The new scheme, MATRIX-VBS, has the potential to significantly advance the representation of organic aerosols in Earth system models by improving upon the conventional representation as non-volatile particulate organic matter, often also with an assumed fixed size distribution. We present results from idealized cases representing Beijing, Mexico City, a Finnish forest, and a southeastern US forest, and investigate the evolution of mass concentrations and volatility distributions for organic species across the gas and particle phases, as well as assessing their mixing state among aerosol populations. Emitted semi-volatile primary organic aerosols evaporate almost completely in the intermediatevolatility range, while they remain in the particle phase in the low-volatility range. Their volatility distribution at any point in time depends on the applied emission factors, oxidation by $\mathrm{OH}$ radicals, and temperature. We also compare against parallel simulations with the original scheme, which represented only the particulate and non-volatile component of the organic aerosol, examining how differently the condensedphase organic matter is distributed across the mixing states in the model. The results demonstrate the importance of representing organic aerosol as a semi-volatile aerosol, and explic-
\end{abstract}

itly calculating the partitioning of organic species between the gas and particulate phases.

\section{Introduction}

Atmospheric aerosols play a key role in the Earth system with great impacts on global air quality, public health, and climate (Boucher et al., 2013; Myhre et al., 2013; Seinfeld and Pandis, 2016). One contribution to the large uncertainty in aerosol radiative forcing is organic aerosol (OA), which is ubiquitous in the atmosphere and contributes to a large portion of submicron particulate mass in various regions around the world (Zhang et al., 2007; Jimenez et al., 2009). Advancements in measurement techniques greatly improved our understanding of the evolution of OA and its lifetime in the atmosphere at the process level (Jimenez et al., 2009). However, OA processes in models still remain poorly constrained. Measurements imply that OA concentrations are potentially underestimated in current models (Tsigaridis et al., 2014). Such a discrepancy hints at large uncertainties in the prediction of aerosol-radiation interactions, their hygroscopicity, aerosol-cloud interactions, and their overall impact on climate (Petters and Kreidenweis, 2007).

Missing sources of secondary organic aerosol (SOA) in models have been suggested to be the main cause of the underestimated OA formation (Heald et al., 2005; Volkamer et al., 2006; Hodzic et al., 2010; Spracklen et al., 2011). More recently, studies have sought to investigate the underestimation of organic aerosol mass within more advanced model frameworks, which are capable of resolving semi-volatile 
primary organic aerosol (POA) and including SOA from a wider set of precursors including intermediate-volatility organic compounds (IVOCs). The volatility-basis set (VBS) was developed (Donahue et al., 2006) to provide a relatively simple framework whereby models can represent the overall behavior of the myriad of compounds that constitute organic aerosol and their precursors. The approach involves considering OA as being composed of a number of representative species, each with a particular volatility, spanning a spectrum in vapor pressures from highly volatile (which essentially remains in the gas phase) to very low vapor pressure species which partition readily into the particle phase. VBS then captures the chemical aging of the organic species in the gas phase, with the hydroxyl radical oxidizing them and producing the adjacent lower-volatility class as a product. This method has been used extensively in regional studies (Robinson et al., 2007; Shrivastava et al., 2008; Murphy and Pandis, 2009; Tsimpidi et al., 2010, 2011; Hodzic et al., 2010; Fountoukis et al., 2011, 2014; Bergström et al., 2012; Athanasopoulou et al., 2013; Zhang et al., 2013) but less so in global models (Pye and Seinfeld, 2010; Jathar et al., 2011; Jo et al., 2013; Tsimpidi et al., 2014; Hodzic et al., 2016). Other studies have used the 2-D VBS (Donahue et al., 2011; Murphy et al., 2011), an approach that, in addition to the volatility space, also resolves that of chemical composition, by tracking the amount of oxygenation in the representative organic compounds. However, the 2-D VBS is not implemented in global models, due to its large number of tracers and the large number of free parameters that are involved in the parameterization.

The inclusion of semi-volatile organics is important for accounting for the total mass of organics in the particulate phase, since an increase in particulate organic matter may not be the result of chemically produced low-volatility species, but simply be reflecting a temperature-driven increase in the partitioning of semi-volatile organic aerosol into the particle phase. It has been established that the highly oxidized, very low volatility organics play a key role in particle formation (Metzger et al., 2010; Paasonen et al., 2013; Riccobono et al., 2014; Kirkby et al., 2016) and particle growth (Tröstl et al., 2016), while the range of volatilities contributing to aerosol growth increases with aerosol size (Pierce et al., 2011; Yu, 2011). Semi-volatile organics also affect aerosol size and mixing state, as well as their impact on climate, due to changes in cloud condensation nuclei $(\mathrm{CCN})$ formation rates (Petters et al., 2006, Riipenen et al., 2011; Scott et al., 2015), hygroscopicity (Petters and Kreidenweis, 2007), and optical properties (Myhre et al., 2013). Since OA emissions are on the rise from developing countries (Lamarque et al., 2010) and no Earth system model considers anthropogenic $\mathrm{OA}$ as semi-volatile as measurements suggest, it is important to include and constrain semi-volatile organics to ultimately reduce uncertainties in aerosol radiative forcing and make climate-model-simulated aerosol changes more realistic.
The objective of this study is to further develop an aerosol microphysics model by including a more advanced representation of organic aerosol, including semi-volatile primary OA and an evolving OA volatility during chemical aging in the gas phase, in its calculations. This objective was achieved by implementing the VBS framework in the aerosol microphysical scheme MATRIX (Multiconfiguration Aerosol TRacker of mIXing state; Bauer et al., 2008), which represents major aerosol processes such as nucleation, condensation (excluding organics in its original version), and coagulation, and explicitly tracks the mixing state of different aerosol populations. As many traditional chemistry-climate models do (Tsigaridis et al., 2014), MATRIX treats POA and SOA as non-volatile (Bauer et al., 2008). By coupling MATRIX with VBS, POA are treated as condensable semi-volatile organic compounds. These can partition among different aerosol populations based on their volatility and aerosol population size distribution, capturing particle growth via condensation of low-volatility organic vapors and thus providing a more physically based calculation of aerosol microphysics.

\section{Model description}

A box model is used for this study. The gas-phase chemical mechanism CBM-IV (Carbon Bond Mechanism IV; Gery et al., 1989), as used in the NASA GISS ModelE (Shindell et al., 2001, 2003), is coupled to the MATRIX aerosol microphysics scheme, utilizing the Kinetic Pre-Processor (KPP; Sandu and Sander, 2006) to solve the differential equations of the gas-phase chemistry scheme. A time step of $30 \mathrm{~min}$ is used, for consistency with the global model.

\subsection{MATRIX box model}

MATRIX (Bauer et al., 2008) is an aerosol microphysical model based on the quadrature method of moments (McGraw, 1997) in the NASA GISS ModelE Earth system model, which can be used either as a module within the global model or as a stand-alone box model. Here, the standalone box model is used for development. The design of the code is such that the box-model code can be used as-is in the global model, without any changes, allowing for seamless transition and maximum portability. MATRIX is designed to resolve the aerosol temporal evolution and represent the mixing states of a user-selected set of aerosol populations, which are modes of different composition as listed in Table 2, tracking two moments each, number and mass, while keeping the width of the distribution fixed. It describes new particle formation, particle growth through condensation with explicit treatment of sulfuric acid condensation, and lumped treatment of the $\mathrm{NH}_{4}-\mathrm{NO}_{3}-\mathrm{H}_{2} \mathrm{O}$ system, as well as coagulation of particles among different populations. Each aerosol population has its own set of aerosol components, which may be primary (from direct aerosol emissions), secondary (formed 
Table 1. Naming convention and parameters used in the VBS implementation described here.

\begin{tabular}{|c|c|c|c|c|c|c|c|c|c|}
\hline Parameter & & & & Virtu: & VBS & pecies & & & \\
\hline$C^{*} \mu \mathrm{g} \mathrm{m}^{-3}$ at $298 \mathrm{~K}$ & $10^{-2}$ & $10^{-1}$ & $10^{0}$ & $10^{1}$ & $10^{2}$ & $10^{3}$ & $10^{4}$ & $10^{5}$ & $10^{6}$ \\
\hline Name of volatility bins & M2 & M1 & M0 & P1 & P2 & P3 & P4 & P5 & P6 \\
\hline $\begin{array}{l}\text { Mass-based emission factors } \\
\text { applied to POA emissions } \\
\text { (Shrivastava et al., 2008) }\end{array}$ & 0.03 & 0.06 & 0.09 & 0.14 & 0.18 & 0.30 & 0.40 & 0.50 & 0.80 \\
\hline Enthalpy of vaporization ${ }^{\mathrm{a}}$ & 153 & 142 & 131 & 120 & 109 & 98 & 87 & 76 & 65 \\
\hline
\end{tabular}

${ }^{a}$ Enthalpy of vaporization is calculated using Eq. (12) from Epstein et al. (2010).

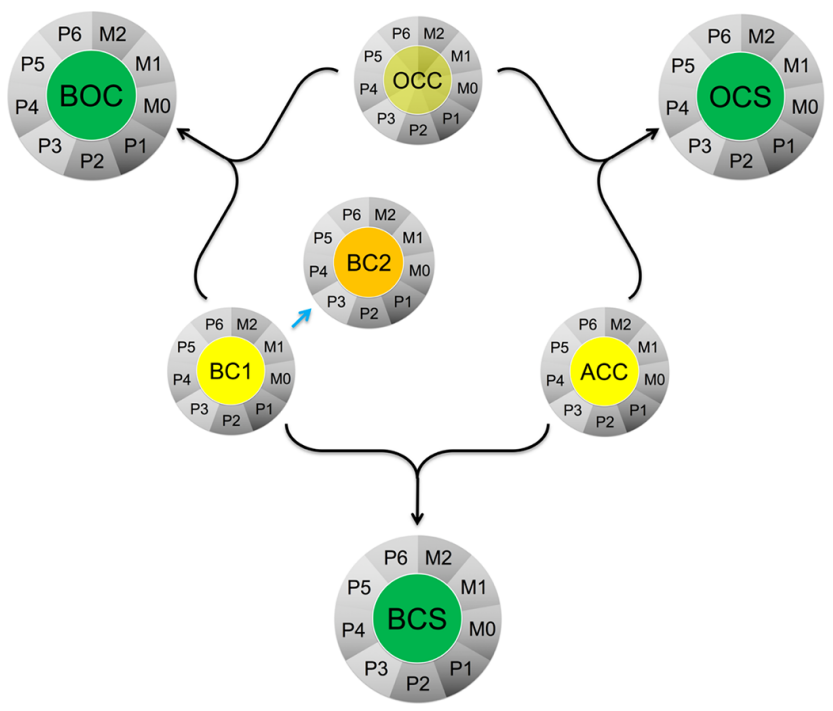

Figure 1. Schematic showing coagulation pathways among organics-containing aerosol populations as colored circles, with nine organic VBS species condensed as grey outer circles. In yellow are the emitted donor aerosol populations, and in green are the mixed recipient populations. OCC has a semi-transparent yellow core because it is actually emitted as the VBS species that can serve as condensation medium for gaseous VBS species, represented by the grey outer circles. In orange is population $\mathrm{BC} 2$, which contains a $>5 \%$ coating of sulfate and organics, which is formed rapidly from the growth of population $\mathrm{BC} 1$, which has $<5 \%$ sulfate and/or organics coating.

by nucleation or condensation of gas-phase components onto existing primary particles), or mixed (from any constituent, following condensation on primary aerosols or coagulation between primary, secondary, or mixed populations).

Black carbon is uniquely treated in MATRIX, in order to separate the coated (via condensation) from the mixed (via coagulation) populations. It is emitted in $\mathrm{BC}$, which can grow (blue arrow in Fig. 1) with inorganic and organic coating, and as its coating volume fraction reaches $5 \%$, it would be moved in the $\mathrm{BC} 2$ population (see Table 2 for a description), shown as the orange circle.

\subsection{VBS framework}

The volatility-basis set approach is introduced to the original model; it is an organic aerosol volatility parameterization that separates semi-volatile organic compounds into logarithmically spaced bins of effective saturation concentrations, which are used for gas-particle partitioning and photochemical aging (Donahue et al., 2006). The scheme groups organic compounds into nine surrogate VBS species according to their effective saturation concentrations $\left(C^{*}\right)$ at $298 \mathrm{~K}$, which are separated by factors of 10 , ranging from $10^{-2}$ to $10^{6} \mu \mathrm{g} \mathrm{m}^{-3}$. We classify organics as Murphy et al. (2014) does: low-volatility organics are in bins $10^{-2}$ to $10^{-1} \mu \mathrm{g} \mathrm{m}{ }^{-3}$ (M2 and M1 in Table 1), semi-volatile organics are in bins $10^{0}$ to $10^{2} \mu \mathrm{g} \mathrm{m}^{-3}$ (M0, P1, P2), and intermediate-volatility organics are in bins $10^{3}$ to $10^{6} \mu \mathrm{g} \mathrm{m}^{-3}$ (P3, P4, P5, and P6). Low-volatility organics partition almost exclusively to the particulate phase, the semi-volatile species are present in both the gas and aerosol phase, and intermediate-volatility organics are the most volatile ones in the framework and remain almost exclusively in the gas phase. Equilibrium partitioning is assumed for all volatility bins. Gas-phase organics can become chemically aged by the extremely reactive hydroxyl radicals $\left({ }^{\circ} \mathrm{OH}\right)$ during daytime with a rate constant of $10^{-11} \mathrm{~cm}^{3} \mathrm{~s}^{-1}$, and as they become more oxidized, their volatility decreases and they move down to the adjacent bin with a factor of 10 lower volatility (Donahue et al., 2006). Parameters and names used to represent them in this study are listed in Table 1.

The emission rates for the VBS species were derived from the POA emission rate in the global model for the corresponding grid box and month, which were distributed in the volatility space by using mass-based emission factors from Shrivastava et al. (2008) (Table 1). Adding up the 9 factors from each bin listed in Table 1, we obtain a total factor of 2.5 , which means the new scheme's organics emission is 2.5 times that of the organics emissions in the original scheme. The additional multiplication factor of 1.5 is applied to the emission to account for missing sources of volatile organics in the IVOC volatility regime in the inventories (Shrivastava et al., 2008). 
Table 2. Aerosol population chemical composition in MATRIX.

\begin{tabular}{|c|c|c|}
\hline $\begin{array}{l}\text { Population } \\
\text { abbreviation }\end{array}$ & Description & $\begin{array}{l}\text { Composition (constituents other } \\
\text { than } \mathrm{NH}_{4}^{+}, \mathrm{NO}_{3}^{-} \text {, and } \mathrm{H}_{2} \mathrm{O} \text { ) }\end{array}$ \\
\hline AKK & sulfate (Aitken mode) & $\mathrm{SO}_{4}^{2-}$ \\
\hline ACC & sulfate (accumulation mode) & $\mathrm{SO}_{4}^{2-}$ \\
\hline OCC & organic carbon & $\mathrm{OC}, \mathrm{SO}_{4}^{2-}$ \\
\hline $\mathrm{BC} 1$ & fresh black carbon $(<5 \%$ coating $)$ & $\mathrm{BC}, \mathrm{SO}_{4}^{2-}$ \\
\hline $\mathrm{BC} 2$ & $\begin{array}{l}\text { aged (by condensation) black carbon } \\
(>5 \% \text { coating) }\end{array}$ & $\mathrm{BC}, \mathrm{SO}_{4}^{2-}$ \\
\hline $\mathrm{BCS}$ & aged (by coagulation) black carbon & $\mathrm{BC}, \mathrm{SO}_{4}^{2-}$ \\
\hline $\mathrm{BOC}$ & black and organic carbon & $\mathrm{BC}, \mathrm{OC}, \mathrm{SO}_{4}^{2-}$ \\
\hline OCS & organic carbon and sulfate & $\mathrm{OC}, \mathrm{SO}_{4}^{2-}$ \\
\hline SSA & sea salt (accumulation mode) & sea salt, $\mathrm{SO}_{4}^{2-}$ \\
\hline SSC & sea salt (coarse mode) & sea salt, $\mathrm{SO}_{4}^{2-}$ \\
\hline DD1 & dust (accumulation mode; $<5 \%$ coating) & mineral dust, $\mathrm{SO}_{4}^{2-}$ \\
\hline DD2 & dust (coarse mode $;<5 \%$ coating) & mineral dust, $\mathrm{SO}_{4}^{2-}$ \\
\hline DS1 & dust (accumulation mode; $>5 \%$ coating) & mineral dust, $\mathrm{SO}_{4}^{2-}$ \\
\hline DS2 & dust (coarse mode; $>5 \%$ coating) & mineral dust, $\mathrm{SO}_{4}^{2-}$ \\
\hline MXX & mixed (all components) & $\mathrm{BC}, \mathrm{OC}$, mineral dust, sea salt, $\mathrm{SO}_{4}^{2-}$ \\
\hline
\end{tabular}

Note: The sigma values for all populations are 1.80, except for AKK, which has a sigma of 1.60, and for SSC and MXX, which both have a sigma of 2.00 .

\section{Model development}

In the original version of the MATRIX model, organics only contribute to particle growth and mix with other aerosol species via coagulation. Primary organic aerosols are emitted only as non-volatile particulate organic matter, and do not exist in the gas phase or interact with other aerosol populations. Implementing the VBS scheme adds these missing processes. Before this development, there were eight alternative configurations of MATRIX available to the user, each representing a distinct set of aerosol populations whose number, composition, and interactions by coagulation vary. A 9th configuration with 15 selected aerosol populations is created for this study (Table 2), in which 8 of the 16 populations, ACC, OCC, BC1, BC2, OCS, BOC, BCS, and MXX, could contain organics as semi-volatile VBS species. We only included semi-volatile organics in eight populations, so that we can examine the BC-OA-sulfate-nitrate system first, before adding them into the nucleation population AKK and the dust and sea salt populations (DD1, DS1, DD2, DS2, SSA, SSC). Through coagulation, the 15 donor populations grow or mix and are placed into recipient populations, based on the donor population composition, as described in Bauer et al. (2008). In a future stage, organics will also be implemented in the AKK mode to present nanoparticle growth, and we will include an additional nucleation scheme that considers the dependence of new particle formation that involve organics (Kirkby et al., 2016; Tröstl et al., 2016).

Previously, each aerosol population carried up to five tracers - sulfate, black carbon, non-volatile organics, dust, and sea salt. Now each of the eight organics-containing populations carry nine additional semi-volatile VBS species listed in Table 1. Together with the 5 original tracers, we now have up to 14 available tracers per population, depending on whether they carry organic aerosols or not, with the original organics tracer (OCAR) representing the non-volatile biogenic OA, as it did in the original mechanism. This newly coupled model MATRIX-VBS treats POA as semi-volatile gas-phase species, which then partition into and out of the particulate phase. The amount of gas-phase species partitioned onto each aerosol population is based on the surface area of that population, in addition to the mass of that population and the volatility of species, and equilibrium partitioning is assumed.

The semi-volatile nature of biogenic SOA is not represented in the VBS framework in this work. Instead, biogenic SOA are treated as non-volatile, as in the original MATRIX version, and are produced with a $10 \%$ constant yield from terpenes emissions without any requirement for oxidation before the OA is formed (Lathière et al., 2005; Tsigaridis et al., 2014). The inclusion of semi-volatile biogenic SOA will be parameterized in the same way as in the VBS framework presented here in the future.

\section{Simulations}

To test the newly developed model's behavior, we simulated idealized cases representative of four different locations and environments: one very polluted city (Beijing), an- 
Table 3. Conditions of each location used in the simulations, taken from the GISS ModelE for January and July 2006.

\begin{tabular}{|c|c|c|c|c|c|c|}
\hline \multicolumn{2}{|c|}{ January 2006} & \multirow{4}{*}{$\begin{array}{l}\text { Units } \\
\mathrm{K} \\
\mathrm{hPa} \\
\%\end{array}$} & \multirow{2}{*}{$\begin{array}{r}\text { Beijing } \\
270\end{array}$} & \multirow{2}{*}{$\begin{array}{r}\text { Centreville } \\
279\end{array}$} & \multirow{2}{*}{$\begin{array}{r}\text { Hyytiälä } \\
260\end{array}$} & \multirow{2}{*}{$\begin{array}{r}\text { Mexico City } \\
283\end{array}$} \\
\hline \multirow{3}{*}{ Fixed parameters } & Temperature & & & & & \\
\hline & Pressure & & 1007 & 996 & 1009 & 797 \\
\hline & RH & & 46.8 & 77.7 & 79.5 & 62.5 \\
\hline \multirow{8}{*}{ Gaseous emissions } & $\mathrm{NO}_{x}$ & \multirow{8}{*}{ pptv $\mathrm{h}^{-1}$} & 216.5 & 92.4 & 169.7 & 148.7 \\
\hline & $\mathrm{CO}$ & & 6943.3 & 1199.3 & 557.3 & 2308.4 \\
\hline & Alkenes & & 4.3 & 0.3 & 0.1 & 1.3 \\
\hline & Paraffin & & 8.2 & 2.1 & 0.6 & 10.5 \\
\hline & Terpenes & & 1.8 & 26.3 & 9.4 & 25.8 \\
\hline & Isoprene & & 1.3 & 23.8 & 0.0 & 0.0 \\
\hline & $\mathrm{SO}_{2}$ & & 555.8 & 191.7 & 24.1 & 538.7 \\
\hline & $\mathrm{NH}_{3}$ & & 181.3 & 24.2 & 50.7 & 63.3 \\
\hline \multirow{3}{*}{ Aerosol emissions } & Sulfate & \multirow{3}{*}{$\mu g \mathrm{~m}^{-3} \mathrm{~h}^{-1}$} & 0.06 & 0.02 & 0.003 & 0.05 \\
\hline & Black carbon & & 0.09 & 0.01 & 0.008 & 0.03 \\
\hline & Organics* & & 0.19 & 0.03 & 0.02 & 0.11 \\
\hline \multicolumn{2}{|c|}{ July 2006} & Units & Beijing & Centreville & Hyytiälä & Mexico City \\
\hline \multirow{3}{*}{ Fixed parameters } & Temperature & $\mathrm{K}$ & 304 & 303 & 292 & 289 \\
\hline & Pressure & $\mathrm{hPa}$ & 986 & 995 & 998 & 800 \\
\hline & $\mathrm{RH}$ & $\%$ & 59.8 & 61.8 & 77.8 & 83.1 \\
\hline \multirow{8}{*}{ Gaseous emissions } & $\mathrm{NO}_{x}$ & \multirow{8}{*}{$\operatorname{pptvh}^{-1}$} & 281.3 & 124.3 & 200.9 & 165.3 \\
\hline & $\mathrm{CO}$ & & 8111.9 & 1749.9 & 630.5 & 2276.1 \\
\hline & Alkenes & & 5.0 & 0.5 & 0.1 & 1.3 \\
\hline & Paraffin & & 9.6 & 2.7 & 0.7 & 10.7 \\
\hline & Terpenes & & 36.9 & 145.4 & 87.6 & 44.9 \\
\hline & Isoprene & & 916.1 & 795.5 & 47.2 & 0.0 \\
\hline & $\mathrm{SO}_{2}$ & & 653.7 & 206.5 & 26.8 & 549.5 \\
\hline & $\mathrm{NH}_{3}$ & & 211.7 & 38.7 & 58.1 & 63.3 \\
\hline \multirow{3}{*}{ Aerosol emissions } & Sulfate & \multirow{3}{*}{$\mu \mathrm{g} \mathrm{m}^{-3} \mathrm{~h}^{-1}$} & 0.06 & 0.02 & 0.002 & 0.05 \\
\hline & Black carbon & & 0.10 & 0.01 & 0.01 & 0.03 \\
\hline & Organics* & & 0.21 & 0.03 & 0.07 & 0.11 \\
\hline
\end{tabular}

* The new scheme's organics emissions are 2.5 times higher than the organics emissions in the original scheme

other cleaner yet still very polluted city at high altitude and closer to the tropics (Mexico City), a very clean Finnish forest (Hyytiälä), and an anthropogenically affected forest in the southeast USA (Centreville, Alabama). The experiments are performed for a winter month (January) and a summer month (July) for 10 days, and initial conditions and emission rates for each location were extracted from a GISS ModelE simulation (similar setup as described in Mezuman et al., 2016) for the year 2006, listed in Table 3. All parameters and emissions are held constant throughout the simulations. Here we do not include deposition and dilution, for simpler massbalance calculations. Semi-volatile POA, sulfate in the accumulation mode, and black carbon are emitted continuously in the $\mathrm{OCC}, \mathrm{ACC}$, and $\mathrm{BC} 1$ populations, respectively, shown in Fig. 1 as yellow circles. Condensation of VBS species on $\mathrm{BC} 1$ can increase the non-absorbing shell of that population, leading to the formation of $\mathrm{BC} 2$, as described above.
The four organics-containing populations described above can coagulate (black arrows in Fig. 1) with themselves and each other and form three additional organics-containing mixed populations, BOC, OCS, and BCS, shown as green circles. This schematic includes seven of the eight organicscontaining populations in the model.

\section{Results and discussion}

The temporal evolution of the total organics mass concentrations from the new scheme and the old scheme are presented in Fig. 2 for January and Fig. 3 for July in the four locations under study. They show large changes in organics concentrations between the old scheme (black line on the right column) and the new one (colors). The organics in the new scheme are represented and distributed by organics tracers of different volatility, whose saturation concentration $C^{*}$ ranges from the least volatile $10^{-2} \mu \mathrm{g} \mathrm{m}^{-3}$ ("M2" in Figs. 2 


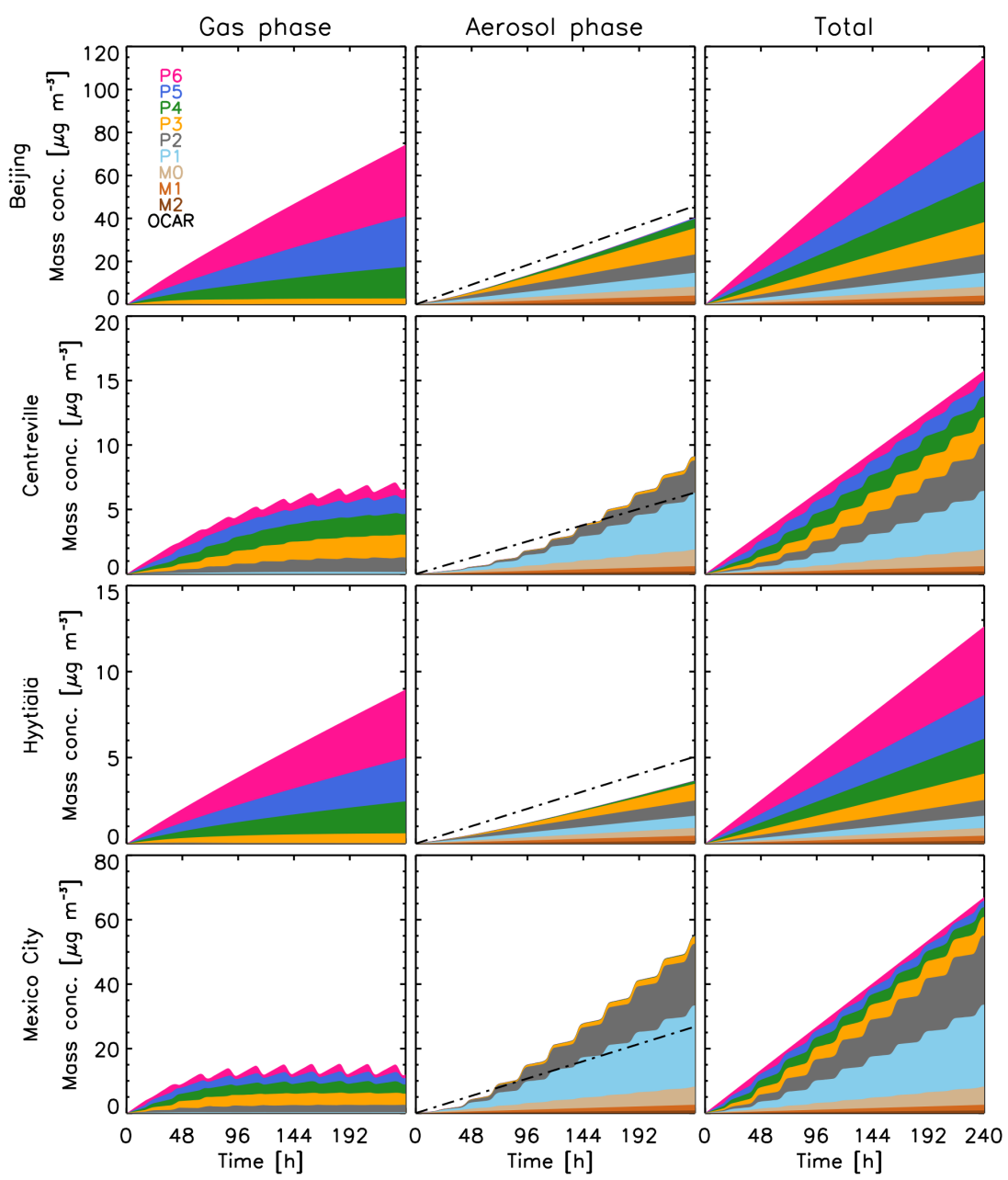

Figure 2. Temporal evolution of the mass concentration of semi-volatile organics in the gas phase (left column), aerosol phase (across all populations; middle column) and total (right column) using the new scheme (refer to Table 1 for legend) for January. The total of non-volatile organics from the original scheme (OCAR) is shown in black dash-dotted lines in the aerosol phase column (middle). OCAR from the old scheme is exactly 2.5 times smaller from the total organic species in the new scheme.

and 3) to the most volatile $10^{6} \mu \mathrm{g} \mathrm{m} \mathrm{m}^{-3}$ ("P6" in Figs. 2 and 3). They are distributed between the gas and aerosol phases by gas-particle partitioning, whereas the organics in the original scheme are only represented by one nonvolatile organic aerosol tracer ("OCAR").

As mentioned in the model description, the emission rates for organics in each of the volatility bins in the new scheme were derived from the Shrivastava et al. (2008) mass-based emission factors. Consequently, since there is no deposition and dilution in the simulations, the new scheme's organics total mass concentrations (shown in color in the right columns of Figs. 2 and 3) always adds up to 2.5 times that of the old scheme (shown as dash-dotted lines) throughout the simulations in both January and July.

\subsection{Winter}

In January, the total mass concentration for organics in Beijing, Centreville, Hyytiälä, and Mexico City at the end of 10 days are approximately $115,16,13$, and $65 \mathrm{\mu g} \mathrm{m}^{-3}$, respectively. Organic VBS species partition between the gas and aerosol phases within their corresponding volatility bin. The more volatile the species, the more it partitions into the gas phase. The concentration evolution of VBS species in the gas phase from the four locations are shown in the left column of Fig. 2 for January. From top to bottom in each panel, volatility decreases from the most volatile species ("P6") to the least volatile ("M2"). Although semi-volatile organics are emitted in the aerosol phase, in the intermediate-volatility range from $\mathrm{P} 6$ to $\mathrm{P} 3$ bins, the species are so volatile that they evaporate and partition into the gas phase almost completely.

In all four locations, almost all species in the intermediatevolatility range are in the gas phase, those in the semi-volatile 

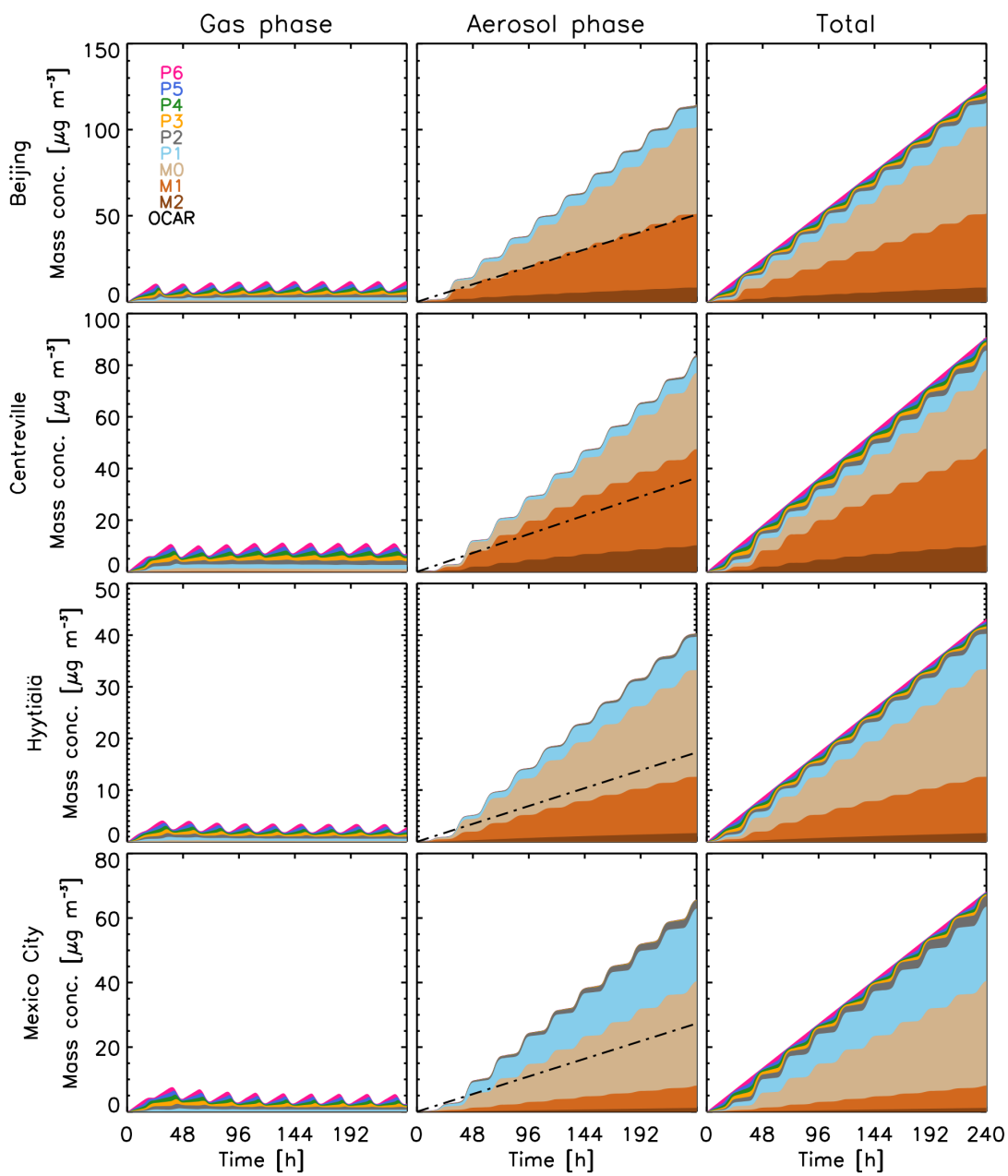

Figure 3. Same as Fig. 2, for July.

range partition between the gas and aerosol phases, and those in the low-volatility range are in the aerosol phase in January. This is especially true for Beijing and Hyytiälä, where the volatility distributions are very similar (in relative terms) and where the total concentration of gas-phase species is higher than the sum of all aerosol-phase species. In Centreville, the total amount of gas-phase species is approximately the same as that of the aerosol-phase species, whereas in Mexico City there are more species in the aerosol phase than in the gas phase. In Centreville and Mexico City, the species show a diurnal variability, which will be explained later.

Aging can help explain the similar volatility distributions in Beijing and Hyytiälä. The ${ }^{\circ} \mathrm{OH}$ concentration in both locations are low in January: Beijing's mean ${ }^{\circ} \mathrm{OH}$ is approximately $10^{5}$ molecules $\mathrm{cm}^{-3}$ and Hyytiälä's mean ${ }^{\cdot} \mathrm{OH}$ is approximately $10^{4}$ molecules $\mathrm{cm}^{-3}$. Low $\cdot \mathrm{OH}$ concentrations limit the aging of intermediate-volatility organics and their ability to move to the lower-volatility bins; thus the volatility distributions do not change drastically, something that is also evident by the lack of a daily cycle. On the other hand, much higher mean ${ }^{\circ} \mathrm{OH}$ concentrations in Centreville $\left(2 \times 10^{6}\right.$ molecules $\left.\mathrm{cm}^{-3}\right)$ and Mexico City $(5 \times$ $10^{6}$ molecules $\mathrm{cm}^{-3}$ ) provide more oxidation power, making oxidation a significant pathway in aerosol evolution. The higher mean ${ }^{\circ} \mathrm{OH}$ concentrations also explain the diurnal variability of both gas-phase and aerosol-phase mass concentrations that we see in the two locations, because ${ }^{\circ} \mathrm{OH}$ is only produced during daytime and has very low concentrations during the night. Since Mexico City has slightly higher ${ }^{\circ} \mathrm{OH}$ concentration than Centreville, its total gas-phase concentration reaches a dynamic equilibrium after approximately 4 days, whereas Centreville's total gas phase continues to rise, approaching equilibrium at a slower pace.

Looking at the total of the organics (right column of Fig. 2), it is not surprising that the very polluted Beijing has the highest concentration of total organics while the cleanest location, Hyytiälä, has the lowest; what is interesting, however, is that organics at these locations share similar volatility distributions. By the end of the 10-day simulations in the new scheme, the volatility distributions in Beijing and Hyytiälä 
are very similar to the emission factor distribution among the volatility, with factor differences of less than 0.1 . This behavior is, again, a result of the low ${ }^{\circ} \mathrm{OH}$ concentrations in the two locations, and the low oxidation rate that limits the change in volatility distribution. Volatility is also temperature dependent, which is also relevant to the total aerosols present. In Beijing, we would expect higher gas-phase concentration due to the higher temperatures. However, the larger amount of aerosols moves the partitioning point towards the aerosol phase, which offsets the temperature difference in the colder Hyytiälä case, and gives us similar results.

On the other hand, the volatility distributions in Centreville and Mexico City are very different from the applied emission factor distribution, except for the two bins in the low-volatility range, M2 and M1. Due to the high concentrations of ${ }^{\bullet} \mathrm{OH}$, both sites have low gas-phase organics concentrations because the intermediate-volatility gases are more efficiently oxidized and their less volatile products partition into the aerosol phase. Therefore, the relative amount of organics from the intermediate-volatility range no longer resembles the applied emission factors. The organics in the intermediate-volatility range from P6 to P3 are totaling factors of approximately 0.38 and 0.15 in Centreville and Mexico City, respectively, which are in sharp contrast to the factors of $0.4,0.5$, and 0.8 applied to each of the respective bins.

\subsection{Summer}

The total mass concentration of organics in Beijing and Mexico City at the end of 10 days in July are approximately 130 and $67 \mu \mathrm{g} \mathrm{m}^{-3}$, respectively, very similar to the amounts in January. However, Centreville and Hyytiälä have higher concentrations of organics than they did in January, with 90 and $43 \mu \mathrm{g} \mathrm{m}^{-3}$, respectively. The volatility distributions for the four locations in July (Fig. 3) are also very different from that of January. Organics are all very low in the intermediatevolatility and semi-volatile ranges, and they are all high in the low-volatility ranges, with less than $10 \%$ of the total organics in the gas phase in all four locations. This behavior means that at all locations, oxidation is very strong, stronger than any place during January. This sharp change in behavior is caused by the difference in ${ }^{\circ} \mathrm{OH}$ concentrations during the 2 months. July's concentrations are much higher than those in January because ${ }^{\circ} \mathrm{OH}$ production is increased due to increased photolysis in the summer. The mean ${ }^{\circ} \mathrm{OH}$ concentration is approximately $1.5 \times 10^{7}$ molecules $\mathrm{cm}^{-3}$ in Beijing and Hyytiälä, and it is approximately $1 \times 10^{7}$ molecules $\mathrm{cm}^{-3}$ in Centreville and $2 \times 10^{7}$ molecules $\mathrm{cm}^{-3}$ in Mexico City. More ${ }^{\bullet} \mathrm{OH}$ leads to faster oxidation of the gas-phase organics and the consequent partitioning of the less-volatile oxidation products into the aerosol phase. This is evident in Fig. 3, where the gas-phase concentrations in all four locations are very low. In all cases, dynamic equilibrium was reached after just 2 days. They also exhibit a strong diurnal variability, as

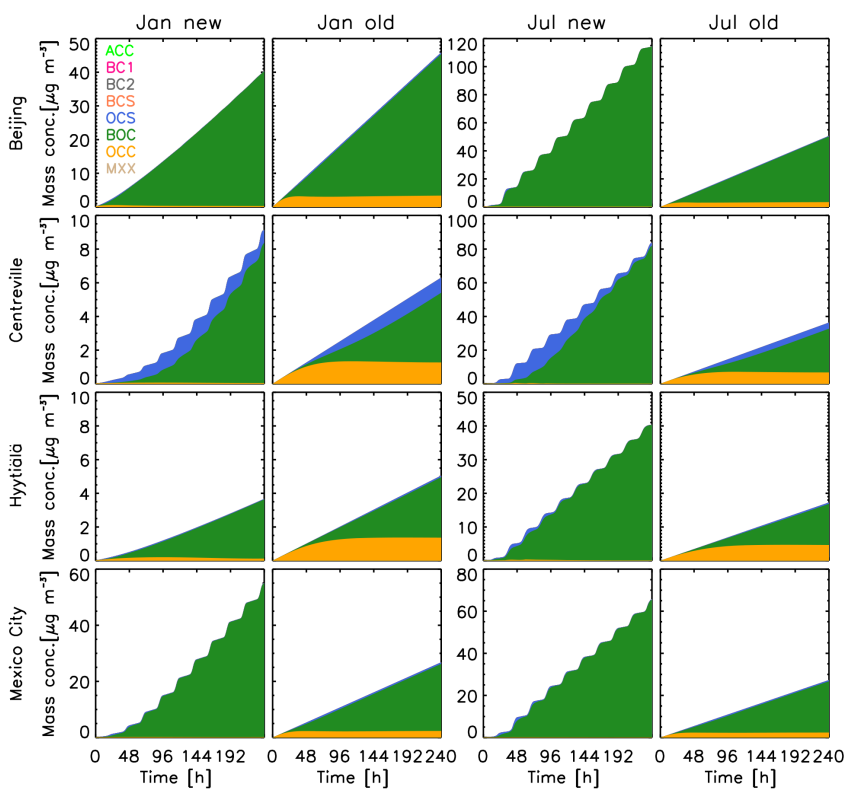

Figure 4. Temporal evolution of organic aerosol mass concentration in each organics-containing population from the new scheme (first column for January, third column for July), and the old scheme (second column for January, fourth column for July).

expected from the fast ${ }^{\bullet} \mathrm{OH}$ oxidation, which decreases with decreasing volatility.

\subsection{Mixing state}

The temporal evolution of total organic aerosol mass concentration per population is shown in Fig. 4 (absolute amounts) and Fig. 5 (relative amounts). The first and third columns are results from the new scheme with condensing and coagulating organics for January and July, respectively, while the second and fourth columns are results from the old scheme with only coagulating organics from January and July, respectively. The organic aerosol mass concentrations in Fig. 4 correspond to the aerosol-phase concentrations in Figs. 2 and 3 (middle column), except they are now separated by population, whereas in the earlier two figures they were separated by mass tracers representing volatility. At a first glance, the population with the highest organic mass is BOC for January and July in both schemes. BOC is the population that contains $\mathrm{OC}, \mathrm{BC}$, and sulfate, and is the end result of coagulation of all populations in our idealized cases. However, in the old scheme, populations OCC and OCS also have significant amounts of organics. This is because in the new scheme the emitted populations are $\mathrm{ACC}, \mathrm{BC} 1$, and $\mathrm{OCC}$, and organics that are emitted in the OCC population can condense on and/or coagulate with other populations, including being lost by evaporation and then repartitioning to other populations. Thus there is an additional loss mechanism of organics from those populations in the new scheme. In addition, there is competition between the $\mathrm{ACC}$ and $\mathrm{BC} 1$ populations 


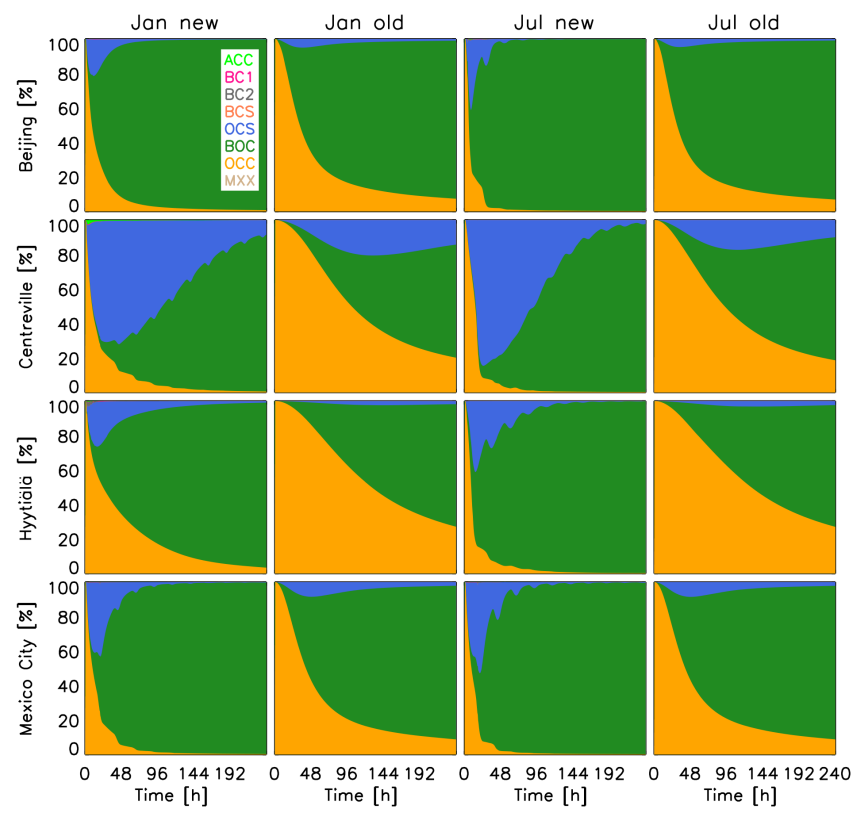

Figure 5. Temporal evolution of organic aerosol mass concentration fraction in each organics-containing population from the new scheme (first column for January, third column for July), and the old scheme (second column for January, fourth column for July).

in both schemes, and in the new scheme, aerosol-phase organics in the OCC population could either coagulate with the ACC population to form OCS, or they could coagulate with the $\mathrm{BC} 1$ population to form BOC. This competition determines how much OCS and BOC are formed, and it affects how much gas-phase organics from the OCC population could condense on the two populations and the distribution of organics among the populations. Since partitioning adds a loss mechanism to OCC, part of the evaporated mass will go to BOC, making it larger, and a more efficient scavenger of other particles. As a result, most organics coagulate with and condense on the BOC population and/or the OCS population, and together with the emitted OCC population, hold the most organics and dominate the mass fractions.

There is some similarity between the January and July results between the new and the old schemes (Fig. 5). This similarity means that the distribution of organics among aerosol populations is not significantly affected by season. This is consistent with a study by Bauer et al. (2013), where they found that the mixing-state distribution is rather a characteristic of a region and not so much of a season, although the total (absolute) amounts by season may vary. By the end of the simulations, most locations have more organics present in the BOC population, except those in Centreville. The reason for this is sulfate; from the sulfate and black carbon emissions listed in Table 3, we can calculate the sulfate-to-blackcarbon ratio in Centreville to be $2: 1$, higher than the corresponding ratios in all other locations. This high ratio helps the ACC population to survive the competition against $\mathrm{BC} 1$ for coagulation with OCC. This leads to higher OCS formation, which is available for gas-phase organics to condense on; thus coagulation and condensation both bring more organics in the OCS population during the first half of the simulation. These results show that the sulfate-to-black-carbon ratio is important for the mixing state by delaying the inevitable BOC domination. Also, comparing the distribution fraction in Fig. 5, volatile organics create rather different mixing states as those created by coagulation alone in the original scheme, meaning that the semi-volatility did alter the mixing state significantly.

\subsection{Size distribution}

Another important factor on the evolution of aerosols is their size distribution. Shown in Figs. 6 and 7 are the January size distributions from Mexico City and Centreville, respectively. The first row shows number concentration, the second row surface area, and the third row volume. The first two columns are results from the new and old schemes after $24 \mathrm{~h}$ of simulation, and the right two columns are after $120 \mathrm{~h}$. The total number concentration, surface area, and volume from the eight populations are shown as dotted lines. Note also that these plots show the total aerosol size distribution per population, which includes the contribution of species other than organics.

The size distributions in July are very similar to January in all locations, and therefore only January is shown here. Beijing, Hyytiälä, and Mexico City exhibit somewhat similar size distributions (with different absolute amounts), just as their mass fractions do. The size distribution is dominated by OCC, OCS, and BOC in the first 3 to 4 days, but later only by BOC. On the other hand, Centreville, similar to its mixing state, is different in its size distribution of different aerosol populations from the other three locations. Therefore, only the size distributions of Mexico City and Centreville are shown here.

In the new scheme for Mexico City after $24 \mathrm{~h}$ of simulation, the number concentration has two modes. OCC has even smaller size than Aitken mode sulfate AKK does, as a result of the evaporation of organics, but its number concentration is higher. OCS and BOC have started to form from coagulation of OCC with $\mathrm{ACC}$ and $\mathrm{BC} 1$, and their diameter, number concentration, surface area, and volume are very similar, almost overlapping, with BOC slightly smaller in diameter. After $120 \mathrm{~h}$ of simulation, OCC's number concentration has decreased significantly, from $4 \times 10^{7}$ to $1 \times 10^{7} \mathrm{~m}^{-3}$. This is because OCC is semi-volatile, it has evaporated and condensed onto other populations, and at the same time its loss due to coagulation with other populations has increased, due to the increase of their number concentration and decrease in size. OCS size grew very slightly, but BOC grew significantly, with peaks of surface area and volume both increasing approximately 1 order of magnitude. Its peak surface area in-

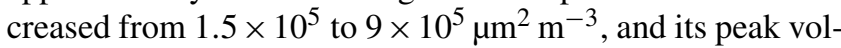




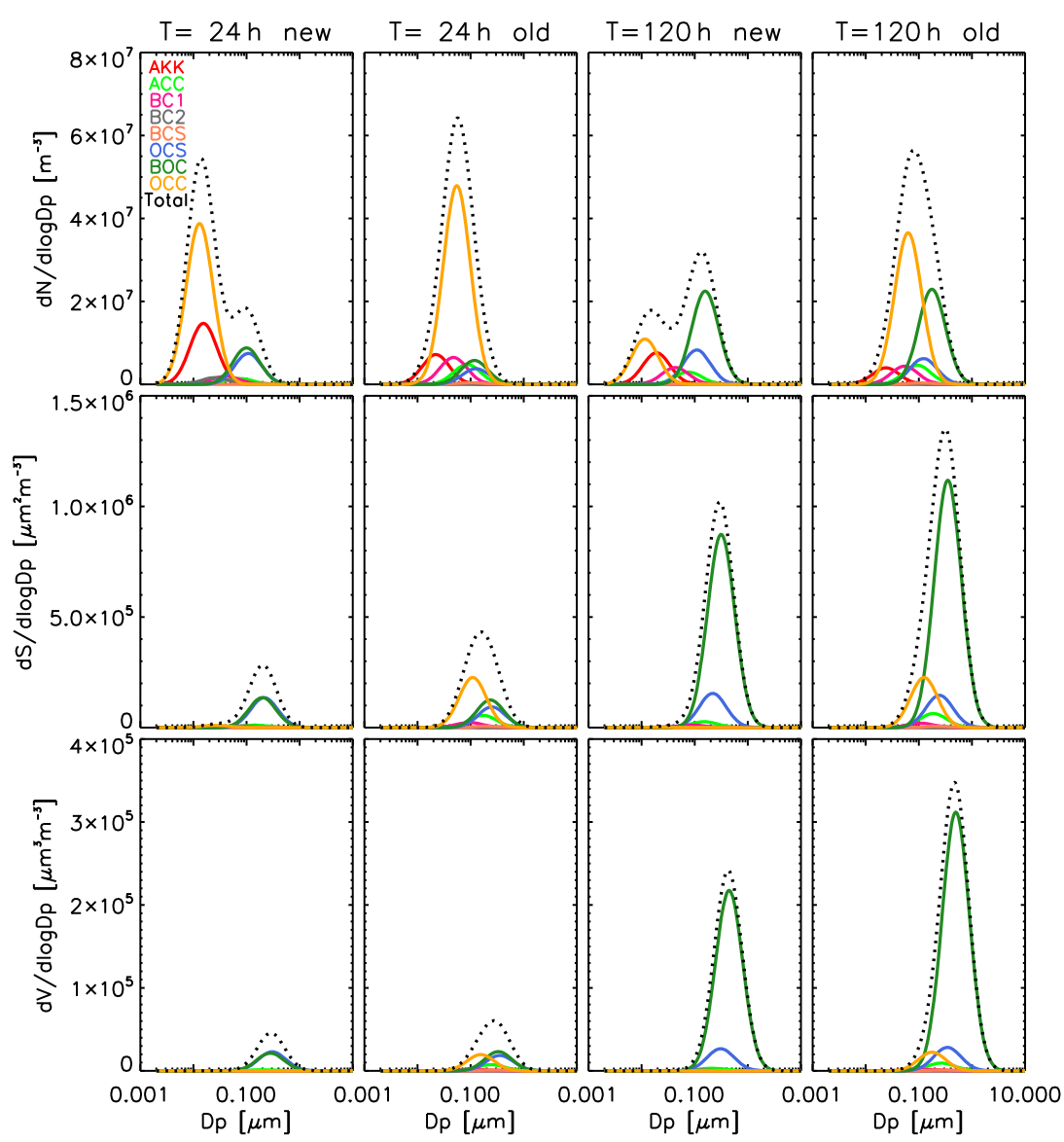

Figure 6. Organics-containing aerosol populations (except MXX) and AKK (Aitken mode sulfate) size distributions for Mexico City in January. Top row: number concentration. Middle row: surface area. Bottom row: volume. Total of all populations in dotted black lines.

ume grew from approximately $2 \times 10^{4}$ to $2 \times 10^{5} \mu^{3} \mathrm{~m}^{-3}$. BOC's growing large surface area is another reason why it has so many organics and dominates the mass concentration: the greater the surface area, the more gas-phase species are able to condense. This matches the mixing-state results (Fig. 5), where we saw after $24 \mathrm{~h}$ that ACC, OCC, and BOC have high mass fractions, whereas after $120 \mathrm{~h}$ OCC and OCS are negligible, and more than $90 \%$ of the total organic aerosol mass is in the BOC population.

In the old scheme, after $24 \mathrm{~h}$ OCC has higher number concentration (peaking at $5 \times 10^{7} \mathrm{~m}^{-3}$ ) and size than in the new scheme, and higher surface area and volume, due to its greater number and diameter. OCS and BOC are both fewer in number (peaks are $1 \times 10^{7}$ and $1.5 \times 10^{7} \mathrm{~m}^{-3}$ lower in the old scheme) but slightly greater in diameter than they are in the new scheme. Later, after $120 \mathrm{~h}, \mathrm{OCC}$ number concentration maximum decreases to $3.5 \times 10^{7} \mathrm{~m}^{-3}$, due to coagulation with ACC and BC1 to form more OCS and BOC. Therefore, OCS and BOC increased in number and size, with BOC seeing greater growth (the peak of number concentration increased from $7 \times 10^{6}$ to $2.3 \times 10^{7} \mathrm{~m}^{-3}$, the peak of surface area increased from $1.5 \times 10^{5}$ to $1.1 \times 10^{6} \mu \mathrm{m}^{2} \mathrm{~m}^{-3}$ and the peak of volume increased from $3 \times 10^{4} \mu^{3} \mathrm{~m}^{-3}$ to $3.1 \times 10^{5} \mu \mathrm{m}^{2} \mathrm{~m}^{-3}$ ). For OCS we calculated more modest increases of approximately $50 \%$ in number, surface area, and volume concentration peaks: the number concentration from $4 \times 10^{6}$ to $7 \times 10^{6} \mathrm{~m}^{-3}$, surface area from $1 \times 10^{5}$ to $1.5 \times$ $10^{5} \mu \mathrm{m}^{2} \mathrm{~m}^{-3}$ and volume from $2 \times 10^{4}$ to $4 \times 10^{4} \mu \mathrm{m}^{3} \mathrm{~m}^{-3}$, as seen in the new scheme as well. However, BOC's growth in the old scheme is even greater than that in the new scheme. This slightly accelerated growth slows down at later hours (not shown), because BOC dominates faster in the new scheme than in the old one (Fig. 4).

The Centreville size distributions tell a different story. In the early stages of the new scheme, OCS has greater number concentration and size than BOC does; OCS's peak number concentration is $0.5 \times 10^{7} \mathrm{~m}^{-3}$, more than double than that of BOC, while its peak surface area and volume are $1 \times 10^{5} \mu \mathrm{m}^{2} \mathrm{~m}^{-3}$ and $2 \times 10^{5} \mu \mathrm{m}^{3} \mathrm{~m}^{-3}$, respectively, whereas those of BOC are negligible. Later, OCS still outgrows BOC in number, but barely exceeds in surface area and is not greater in volume. BOC shifts to greater diameters, therefore it has greater volume than OCS does after $120 \mathrm{~h}$. As for the old scheme, OCC does not decrease in number from 24 


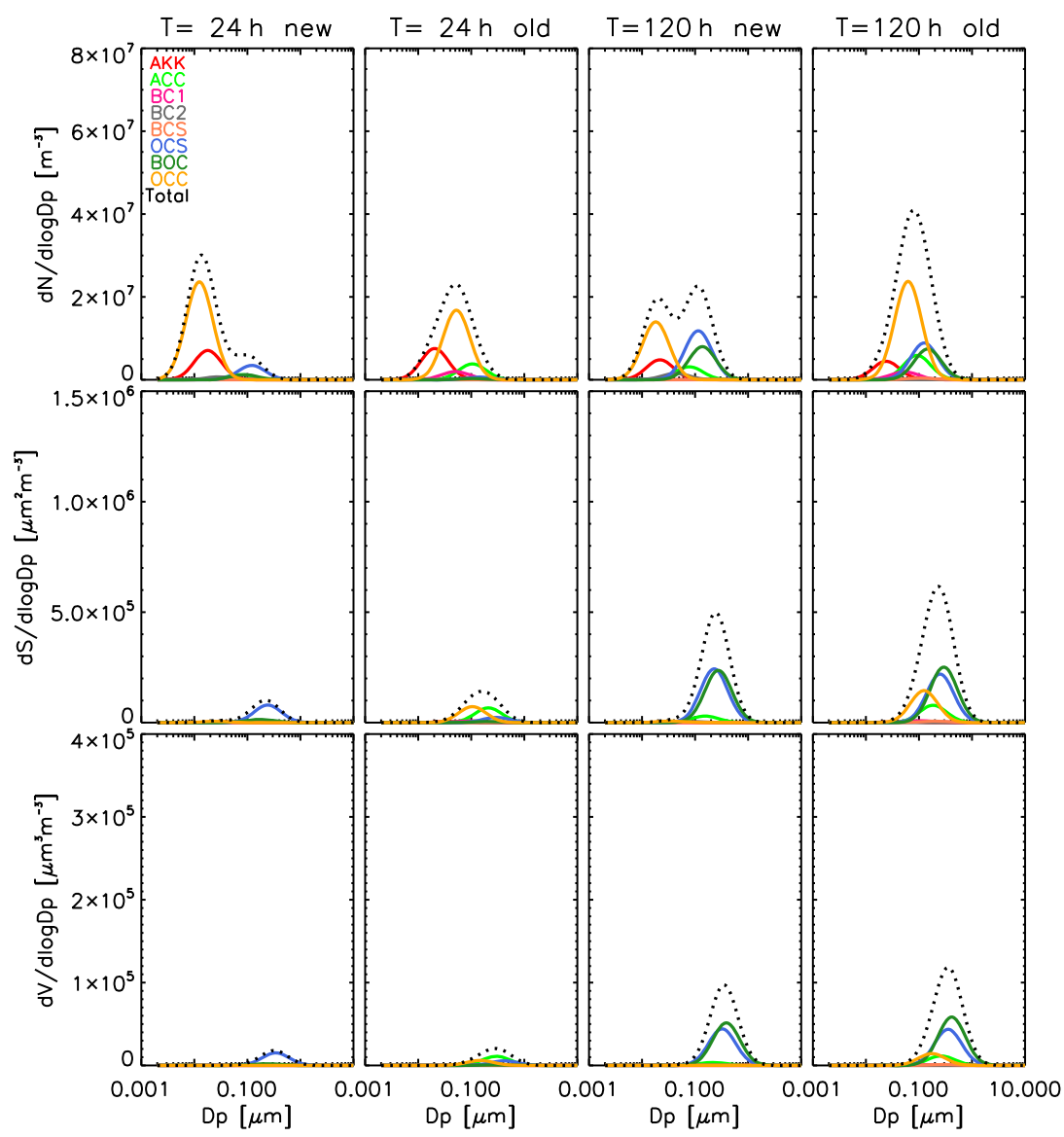

Figure 7. Same as Fig. 6 for Centreville.

to $120 \mathrm{~h}$ as it does in Mexico City, but its number increases from $1.7 \times 10^{7}$ to $2.5 \times 10^{7} \mathrm{~m}^{-3}$. This means that in that period of time coagulation, loss is less than the amount of OCC emitted, which is what was also seen earlier for the mass concentrations (Fig. 2). At $120 \mathrm{~h}$, OCS has again higher number concentration than BOC does, but only slightly (peak number concentration difference is approximately $1 \times 10^{6} \mathrm{~m}^{-3}$ ) and not as much as in the case of Mexico City, and the latter's surface area and volume continue to be greater than those of the former due to its increasing diameter.

\section{Conclusions}

Organic aerosol volatility calculations were implemented into a new aerosol microphysics scheme, MATRIXVBS. Results from idealized cases in Beijing, Centreville, Hyytiälä, and Mexico City during summer and winter using the new scheme were compared against the original scheme and showed how the inclusion of semi-volatility of organics and their reactivity affected aerosol mass concentration, as well as their mixing state and size distribution. Emission factors, ${ }^{\circ} \mathrm{OH}$ oxidation, temperature, and total aerosol levels are the key factors determining organics' volatility distribution and mass concentration. The mixing state is affected by particle size and concentration, which determines coagulation and condensation pathways. Results from the new scheme showed different mixing-state distribution from the original scheme.

Going forward, the new scheme will be simplified, and we will reduce the number of tracers needed in order to simplify the model and save computational resources, without losing the essential information needed for volatility. The simplified version of the box model will then be implemented in the NASA GISS ModelE Earth system model. While this study is purely theoretical, we will evaluate MATRIX-VBS after its implementation into GISS ModelE. We will gain even better understanding of how semi-volatile organics are altering aerosol mixing state, how meteorological conditions and pollution levels influence organics' volatility distribution (as well as their mixing state in the real world), and what implications these processes have on the climate system. 


\section{Code availability}

This model development is part of GISS ModelE Earth system model, which is publicly available. In addition, the box model used here is available on request.

Competing interests. The authors declare that they have no conflict of interest.

Acknowledgements. We thank the NASA Modeling, Analysis, and Prediction program, which supports the GISS ModelE development.

Edited by: G. Mann

Reviewed by: three anonymous referees

\section{References}

Athanasopoulou, E., Vogel, H., Vogel, B., Tsimpidi, A. P., Pandis, S. N., Knote, C., and Fountoukis, C.: Modeling the meteorological and chemical effects of secondary organic aerosols during an EUCAARI campaign, Atmos. Chem. Phys., 13, 625-645, doi:10.5194/acp-13-625-2013, 2013.

Bauer, S. E., Wright, D. L., Koch, D., Lewis, E. R., McGraw, R., Chang, L.-S., Schwartz, S. E., and Ruedy, R.: MATRIX (Multiconfiguration Aerosol TRacker of mIXing state): an aerosol microphysical module for global atmospheric models, Atmos. Chem. Phys., 8, 6003-6035, doi:10.5194/acp-8-60032008, 2008.

Bauer, S. E., Ault, A., and Prather, K. A.: Evaluation of aerosol mixing state classes in the GISS modelE-MATRIX climate model using single-particle mass spectrometry measurements, J. Geophys. Res.-Atmos., 118, 9834-9844, doi:10.1002/jgrd.50700, 2013.

Bergström, R., Denier van der Gon, H. A. C., Prévôt, A. S. H., Yttri, K. E., and Simpson, D.: Modelling of organic aerosols over Europe (2002-2007) using a volatility basis set (VBS) framework: application of different assumptions regarding the formation of secondary organic aerosol, Atmos. Chem. Phys., 12, 8499-8527, doi:10.5194/acp-12-8499-2012, 2012.

Boucher, O., Randall, D., Artaxo, P., Bretherton, C., Feingold, G., Forster, P., Kerminen, V.-M., Kondo, Y., Liao, H., Lohmann, U., Rasch, P., Satheesh, S. K., Sherwood, S., Stevens, B., and Zhang, X. Y.: Clouds and Aerosols, in: Climate Change 2013: The Physical Science Basis. Contribution of Working Group I to the Fifth Assessment Report of the Intergovernmental Panel on Climate Change, edited by: Stocker, T. F., Qin, D., Plattner, G.-K., Tignor, M., Allen, S. K., Boschung, J., Nauels, A., Xia, Y., Bex, V., and Midgley, P. M., Cambridge University Press, Cambridge, UK and New York, NY, USA, 571-657 pp., doi:10.1017/CBO9781107415324, 2013.

Donahue, N. M., Robinson, A. L., Stanier, C. O., and Pandis, S. N.: Coupled partitioning, dilution, and chemical aging of semivolatile organics, Environ. Sci. Technol., 40, 2635-2643, doi:10.1021/es052297c, 2006.
Donahue, N. M., Epstein, S. A., Pandis, S. N., and Robinson, A. L.: A two-dimensional volatility basis set: 1. organic-aerosol mixing thermodynamics, Atmos. Chem. Phys., 11, 3303-3318, doi:10.5194/acp-11-3303-2011, 2011.

Epstein, S. A., Riipinen, I., and Donahue, N. M.: A Semi-Empirical Correlation between Enthalpy of Vaporization and Saturation Concentration for Organic Aerosol, Environ. Sci. Technol., 44, 743-748, doi:10.1021/es902497z, 2010.

Fountoukis, C., Racherla, P. N., Denier van der Gon, H. A. C., Polymeneas, P., Charalampidis, P. E., Pilinis, C., Wiedensohler, A., Dall'Osto, M., O'Dowd, C., and Pandis, S. N.: Evaluation of a three-dimensional chemical transport model (PMCAMx) in the European domain during the EUCAARI May 2008 campaign, Atmos. Chem. Phys., 11, 10331-10347, doi:10.5194/acp11-10331-2011, 2011.

Fountoukis, C., Megaritis, A. G., Skyllakou, K., Charalampidis, P. E., Pilinis, C., Denier van der Gon, H. A. C., Crippa, M., Canonaco, F., Mohr, C., Prévôt, A. S. H., Allan, J. D., Poulain, L., Petäjä, T., Tiitta, P., Carbone, S., Kiendler-Scharr, A., Nemitz, E., O'Dowd, C., Swietlicki, E., and Pandis, S. N.: Organic aerosol concentration and composition over Europe: insights from comparison of regional model predictions with aerosol mass spectrometer factor analysis, Atmos. Chem. Phys., 14, 9061-9076, doi:10.5194/acp-14-9061-2014, 2014.

Gery, M. W., Whitten, G. Z., Killus, J. P., and Dodge, M. C.: A photochemical kinetics mechanism for urban and regional scale computer modeling, J. Geophys. Res., 94, 12925-12956, doi:10.1029/JD094iD10p12925, 1989.

Heald, C. L., Jacob, D. J., Park, R. J., Russell, L. M., Huebert, B. J., Seinfeld, J. H., Liao, H., and Weber, R. J.: A large organic aerosol source in the free troposphere missing from current models, Geophys. Res. Lett., 32, 1-4, doi:10.1029/2005GL023831, 2005.

Hodzic, A., Jimenez, J. L., Madronich, S., Canagaratna, M. R., DeCarlo, P. F., Kleinman, L., and Fast, J.: Modeling organic aerosols in a megacity: potential contribution of semi-volatile and intermediate volatility primary organic compounds to secondary organic aerosol formation, Atmos. Chem. Phys., 10, 5491-5514, doi:10.5194/acp-10-5491-2010, 2010.

Hodzic, A., Kasibhatla, P. S., Jo, D. S., Cappa, C. D., Jimenez, J. L., Madronich, S., and Park, R. J.: Rethinking the global secondary organic aerosol (SOA) budget: stronger production, faster removal, shorter lifetime, Atmos. Chem. Phys., 16, 7917-7941, doi:10.5194/acp-16-7917-2016, 2016.

Jathar, S. H., Farina, S. C., Robinson, A. L., and Adams, P. J.: The influence of semi-volatile and reactive primary emissions on the abundance and properties of global organic aerosol, Atmos. Chem. Phys., 11, 7727-7746, doi:10.5194/acp-11-77272011, 2011.

Jimenez, J. L., Canagaratna, M. R., Donahue, N. M., Prevot, A. S. H., Zhang, Q., Kroll, J. H., DeCarlo, P. F., Allan, J. D., Coe, H., Ng, N. L., Aiken, A. C., Docherty, K. S., Ulbrich, I. M., Grieshop, A. P., Robinson, A. L., Duplissy, J., Smith, J. D., Wilson, K. R., Lanz, V. A., Hueglin, C., Sun, Y. L., Tian, J., Laaksonen, a, Raatikainen, T., Rautiainen, J., Vaattovaara, P., Ehn, M., Kulmala, M., Tomlinson, J. M., Collins, D. R., Cubison, M. J., Dunlea, E. J., Huffman, J. A., Onasch, T. B., Alfarra, M. R., Williams, P. I., Bower, K., Kondo, Y., Schneider, J., Drewnick, F., Borrmann, S., Weimer, S., Demerjian, K., 
Salcedo, D., Cottrell, L., Griffin, R., Takami, A., Miyoshi, T., Hatakeyama, S., Shimono, A., Sun, J. Y., Zhang, Y. M., Dzepina, K., Kimmel, J. R., Sueper, D., Jayne, J. T., Herndon, S. C., Trimborn, A. M., Williams, L. R., Wood, E. C., Middlebrook, A. M., Kolb, C. E., Baltensperger, U., and Worsnop, D. R.: Evolution of organic aerosols in the atmosphere, Science, 326, 1525-1529, doi:10.1126/science.1180353, 2009.

Jo, D. S., Park, R. J., Kim, M. J., and Spracklen, D. V.: Effects of chemical aging on global secondary organic aerosol using the volatility basis set approach, Atmos. Environ., 81, 230-244, 2013.

Kirkby, J., Duplissy, J., Sengupta, K., Frege, C., Gordon, H., Williamson, C., Heinritzi, M., Simon, M., Yan, C., and Almeida, J.: Ion-induced nucleation of pure biogenic particles, Nature, 533, 521-526, doi:10.1038/nature17953, 2016.

Lamarque, J.-F., Bond, T. C., Eyring, V., Granier, C., Heil, A., Klimont, Z., Lee, D., Liousse, C., Mieville, A., Owen, B., Schultz, M. G., Shindell, D., Smith, S. J., Stehfest, E., Van Aardenne, J., Cooper, O. R., Kainuma, M., Mahowald, N., McConnell, J. R., Naik, V., Riahi, K., and van Vuuren, D. P.: Historical (1850-2000) gridded anthropogenic and biomass burning emissions of reactive gases and aerosols: methodology and application, Atmos. Chem. Phys., 10, 7017-7039, doi:10.5194/acp10-7017-2010, 2010.

Lathière, J., Hauglustaine, D. A., De Noblet-Ducoudré, N., Krinner, G., and Folberth, G. A.: Past and future changes in biogenic volatile organic compound emissions simulated with a global dynamic vegetation model, Geophys. Res. Lett., 32, L20818, doi:10.1029/2005GL024164, 2005.

McGraw, R.: Description of Aerosol Dynamics by the Quadrature Method of Moments, Aerosol Sci. Tech., 27, 255-265, doi:10.1080/02786829708965471, 1997.

Metzger, A., Verheggen, B., Dommen, J., Duplissy, J., Prevot, A. S. H., Weingartner, E., Riipinen, I., Kulmala, M., Spracklen, D. V., Carslaw, K. S., and Baltensperger, U.: Evidence for the role of organics in aerosol particle formation under atmospheric conditions, P. Natl. Acad. Sci. USA, 107, 6646-6651, doi:10.1073/pnas.0911330107, 2010.

Mezuman, K., Bauer, S. E., and Tsigaridis, K.: Evaluating secondary inorganic aerosols in three dimensions, Atmos. Chem. Phys., 16, 10651-10669, doi:10.5194/acp-16-10651-2016, 2016.

Murphy, B. N. and Pandis, S. N.: Simulating the formation of semivolatile primary and secondary organic aerosol in a regional chemical transport model, Environ. Sci. Technol., 43, 47224728, doi:10.1021/es803168a, 2009.

Murphy, B. N., Donahue, N. M., Fountoukis, C., and Pandis, S. N.: Simulating the oxygen content of ambient organic aerosol with the 2D volatility basis set, Atmos. Chem. Phys., 11, 7859-7873, doi:10.5194/acp-11-7859-2011, 2011.

Murphy, B. N., Donahue, N. M., Robinson, A. L., and Pandis, S. N.: A naming convention for atmospheric organic aerosol, Atmos. Chem. Phys., 14, 5825-5839, doi:10.5194/acp-14-58252014, 2014.

Myhre, G., Shindell, D., Bréon, F.-M., Collins, W., Fuglestvedt, J., Huang, J., Koch, D., Lamarque, J.-F., Lee, D., Mendoza, B., Nakajima, T., Robock, A., Stephens, G., Takemura T., and Zhang, H.: Anthropogenic and Natural Radiative Forcing, in: Climate Change 2013: The Physical Science Basis. Contribution of Working Group I to the Fifth Assessment Report of the Inter- governmental Panel on Climate Change, edited by: Stocker, T. F., Qin, D., Plattner, G.-K., Tignor, M., Allen, S. K., Boschung, J., Nauels, A., Xia, Y., Bex, V., and Midgley, P. M., Cambridge University Press, Cambridge, UK and New York, NY, USA, 659740, doi:10.1017/CBO9781107415324, 2013.

Paasonen, P., Asmi, A., Petäjä, T., Kajos, M. K., Äijälä, M., Junninen, H., Holst, T., Abbatt, J. P. D., Arneth, A., Birmili, W., van der Gon, H. D., Hamed, A., Hoffer, A., Laakso, L., Laaksonen, A., Richard Leaitch, W., Plass-Dülmer, C., Pryor, S. C., Räisänen, P., Swietlicki, E., Wiedensohler, A., Worsnop, D. R., Kerminen, V.-M., and Kulmala, M.: Warming-induced increase in aerosol number concentration likely to moderate climate change, Nat. Geosci., 6, 438-442, doi:10.1038/ngeo1800, 2013.

Petters, M. D. and Kreidenweis, S. M.: A single parameter representation of hygroscopic growth and cloud condensation nucleus activity, Atmos. Chem. Phys., 7, 1961-1971, doi:10.5194/acp-71961-2007, 2007.

Petters, M. D., Prenni, A. J., Kreidenweis, S. M., DeMott, P. J., Matsunaga, A., Lim, Y. B., and Ziemann, P. J.: Chemical aging and the hydrophobic-hydrophilic conversion of carbonaceous aerosol, Geophys. Res. Lett., 33, L24806, doi:10.1029/2006GL027249, 2006.

Pierce, J. R., Riipinen, I., Kulmala, M., Ehn, M., Petäjä, T., Junninen, H., Worsnop, D. R., and Donahue, N. M.: Quantification of the volatility of secondary organic compounds in ultrafine particles during nucleation events, Atmos. Chem. Phys., 11, 90199036, doi:10.5194/acp-11-9019-2011, 2011.

Pye, H. O. T. and Seinfeld, J. H.: A global perspective on aerosol from low-volatility organic compounds, Atmos. Chem. Phys., 10, 4377-4401, doi:10.5194/acp-10-4377-2010, 2010.

Riccobono, F., Schobesberger, S., Scott, C. E., Dommen, J., Ortega, I. K., Rondo, L., Almeida, J., Amorim, A., Bianchi, F., Breitenlechner, M., David, A., Downard, A., Dunne, E. M., Duplissy, J., Ehrhart, S., Flagan, R. C., Franchin, A., Hansel, A., Junninen, H., Kajos, M., Keskinen, H., Kupc, A., Kürten, A., Kvashin, A. N., Laaksonen, A., Lehtipalo, K., Makhmutov, V., Mathot, S., Nieminen, T., Onnela, A., Petäjä, T., Praplan, A. P., Santos, F. D., Schallhart, S., Seinfeld, J. H., Sipilä, M., Spracklen, D. V., Stozhkov, Y., Stratmann, F., Tomé, A., Tsagkogeorgas, G., Vaattovaara, P., Viisanen, Y., Vrtala, A., Wagner, P. E., Weingartner, E., Wex, H., Wimmer, D., Carslaw, K. S., Curtius, J., Donahue, N. M., Kirkby, J., Kulmala, M., Worsnop, D. R., and Baltensperger, U.: Oxidation products of biogenic emissions contribute to nucleation of atmospheric particles, Science, 344, 717721, 2014.

Riipinen, I., Pierce, J. R., Yli-Juuti, T., Nieminen, T., Häkkinen, S., Ehn, M., Junninen, H., Lehtipalo, K., Petäjä, T., Slowik, J., Chang, R., Shantz, N. C., Abbatt, J., Leaitch, W. R., Kerminen, V.-M., Worsnop, D. R., Pandis, S. N., Donahue, N. M., and Kulmala, M.: Organic condensation: a vital link connecting aerosol formation to cloud condensation nuclei (CCN) concentrations, Atmos. Chem. Phys., 11, 3865-3878, doi:10.5194/acp-11-38652011, 2011.

Robinson, A. L., Donahue, N. M., Shrivastava, M. K., Weitkamp, E. A., Sage, A. M., Grieshop, A. P., Lane, T. E., Pierce, J. R., and Pandis, S. N.: Rethinking organic aerosols: semivolatile emissions and photochemical aging, Science, 315, 1259-1262, doi:10.1126/science.1133061, 2007. 
Sandu, A. and Sander, R.: Technical note: Simulating chemical systems in Fortran90 and Matlab with the Kinetic PreProcessor KPP-2.1, Atmos. Chem. Phys., 6, 187-195, doi:10.5194/acp-6187-2006, 2006.

Scott, C. E., Spracklen, D. V., Pierce, J. R., Riipinen, I., D’Andrea, S. D., Rap, A., Carslaw, K. S., Forster, P. M., Artaxo, P., Kulmala, M., Rizzo, L. V., Swietlicki, E., Mann, G. W., and Pringle, K. J.: Impact of gas-to-particle partitioning approaches on the simulated radiative effects of biogenic secondary organic aerosol, Atmos. Chem. Phys., 15, 12989-13001, doi:10.5194/acp-1512989-2015, 2015.

Seinfeld, J. H. and Pandis, S. N.: Atmospheric Chemistry and Physics: From Air Pollution to Climate Change, third edition, John Wiley \& Sons Inc., Hoboken, New Jersey, 2016.

Shindell, D. T., Grenfell, J. L., Rind, D., Grewe, V., and Price, C.: Chemistry-climate interactions in the Goddard Institute for Space Studies general circulation model: 1. Tropospheric chemistry model description and evaluation, J. Geophys. Res., 106, 8047, doi:10.1029/2000JD900704, 2001.

Shindell, D. T., Faluvegi, G., and Bell, N.: Preindustrial-to-presentday radiative forcing by tropospheric ozone from improved simulations with the GISS chemistry-climate GCM, Atmos. Chem. Phys., 3, 1675-1702, doi:10.5194/acp-3-1675-2003, 2003.

Shrivastava, M. K., Lane, T. E., Donahue, N. M., Pandis, S. N., and Robinson, A. L.: Effects of gas particle partitioning and aging of primary emissions on urban and regional organic aerosol concentrations, J. Geophys. Res.-Atmos., 113, D18301, doi:10.1029/2007JD009735, 2008.

Spracklen, D. V., Jimenez, J. L., Carslaw, K. S., Worsnop, D. R., Evans, M. J., Mann, G. W., Zhang, Q., Canagaratna, M. R., Allan, J., Coe, H., McFiggans, G., Rap, A., and Forster, P.: Aerosol mass spectrometer constraint on the global secondary organic aerosol budget, Atmos. Chem. Phys., 11, 12109-12136, doi:10.5194/acp-11-12109-2011, 2011.

Tröstl, J., Chuang, W., Gordon, H., Heinritzi, M., Yan, C., Molteni, U., Ahlm, L., Frege, C., Bianchi, F., and Wagner, R.: The role of low-volatility organic compounds in initial particle growth in the atmosphere, Nature, 533, 527-531, doi:10.1038/nature18271, 2016.

Tsigaridis, K., Daskalakis, N., Kanakidou, M., Adams, P. J., Artaxo, P., Bahadur, R., Balkanski, Y., Bauer, S. E., Bellouin, N., Benedetti, A., Bergman, T., Berntsen, T. K., Beukes, J. P., Bian, H., Carslaw, K. S., Chin, M., Curci, G., Diehl, T., Easter, R. C., Ghan, S. J., Gong, S. L., Hodzic, A., Hoyle, C. R., Iversen, T., Jathar, S., Jimenez, J. L., Kaiser, J. W., Kirkevåg, A., Koch, D., Kokkola, H., Lee, Y. H., Lin, G., Liu, X., Luo, G., Ma, X., Mann, G. W., Mihalopoulos, N., Morcrette, J.-J., Müller, J.-F., Myhre, G., Myriokefalitakis, S., Ng, N. L., O’Donnell, D., Penner, J. E., Pozzoli, L., Pringle, K. J., Russell, L. M., Schulz, M., Sciare, J., Seland, Ø., Shindell, D. T., Sillman, S., Skeie, R. B., Spracklen, D., Stavrakou, T., Steenrod, S. D., Takemura, T., Tiitta, P., Tilmes, S., Tost, H., van Noije, T., van Zyl, P. G., von Salzen, K., Yu, F., Wang, Z., Wang, Z., Zaveri, R. A., Zhang, H., Zhang, K., Zhang, Q., and Zhang, X.: The AeroCom evaluation and intercomparison of organic aerosol in global models, Atmos. Chem. Phys., 14, 10845-10895, doi:10.5194/acp-1410845-2014, 2014.
Tsimpidi, A. P., Karydis, V. A., Zavala, M., Lei, W., Molina, L., Ulbrich, I. M., Jimenez, J. L., and Pandis, S. N.: Evaluation of the volatility basis-set approach for the simulation of organic aerosol formation in the Mexico City metropolitan area, Atmos. Chem. Phys., 10, 525-546, doi:10.5194/acp-10-525-2010, 2010.

Tsimpidi, A. P., Karydis, V. A., Zavala, M., Lei, W., Bei, N., Molina, L., and Pandis, S. N.: Sources and production of organic aerosol in Mexico City: insights from the combination of a chemical transport model (PMCAMx-2008) and measurements during MILAGRO, Atmos. Chem. Phys., 11, 5153-5168, doi:10.5194/acp11-5153-2011, 2011.

Tsimpidi, A. P., Karydis, V. A., Pozzer, A., Pandis, S. N., and Lelieveld, J.: ORACLE (v1.0): module to simulate the organic aerosol composition and evolution in the atmosphere, Geosci. Model Dev., 7, 3153-3172, doi:10.5194/gmd-7-31532014, 2014.

Volkamer, R., Jimenez, J. L., San Martini, F., Dzepina, K., Zhang, Q., Salcedo, D., Molina, L. T., Worsnop, D. R., and Molina, M. J.: Secondary organic aerosol formation from anthropogenic air pollution: Rapid and higher than expected, Geophys. Res. Lett., 33, L17811, doi:10.1029/2006GL026899, 2006.

Yu, F.: A secondary organic aerosol formation model considering successive oxidation aging and kinetic condensation of organic compounds: global scale implications, Atmos. Chem. Phys., 11, 1083-1099, doi:10.5194/acp-11-1083-2011, 2011.

Zhang, Q., Jimenez, J. L., Canagaratna, M. R., Allan, J. D., Coe, H., Ulbrich, I., Alfarra, M. R., Takami, a., Middlebrook, a. M., Sun, Y. L., Dzepina, K., Dunlea, E., Docherty, K., DeCarlo, P. F., Salcedo, D., Onasch, T., Jayne, J. T., Miyoshi, T., Shimono, a., Hatakeyama, S., Takegawa, N., Kondo, Y., Schneider, J., Drewnick, F., Borrmann, S., Weimer, S., Demerjian, K., Williams, P., Bower, K., Bahreini, R., Cottrell, L., Griffin, R. J., Rautiainen, J., Sun, J. Y., Zhang, Y. M., and Worsnop, D. R.: Ubiquity and dominance of oxygenated species in organic aerosols in anthropogenically-influenced Northern Hemisphere midlatitudes, Geophys. Res. Lett., 34, 1-6, doi:10.1029/2007GL029979, 2007.

Zhang, Q. J., Beekmann, M., Drewnick, F., Freutel, F., Schneider, J., Crippa, M., Prevot, A. S. H., Baltensperger, U., Poulain, L., Wiedensohler, A., Sciare, J., Gros, V., Borbon, A., Colomb, A., Michoud, V., Doussin, J. F., Denier Van Der Gon, H. A. C., Haeffelin, M., Dupont, J. C., Siour, G., Petetin, H., Bessagnet, B., Pandis, S. N., Hodzic, A., Sanchez, O., Honoré, C., and Perrussel, O.: Formation of organic aerosol in the Paris region during the MEGAPOLI summer campaign: Evaluation of the volatilitybasis-set approach within the CHIMERE model, Atmos. Chem. Phys., 13, 5767-5790, doi:10.5194/acp-13-5767-2013, 2013. 